DOI: http://dx.doi.org/10.33846/hn50306

http://heanoti.com/index.php/hn

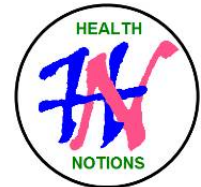

RESEARCH ARTICLE

URL of this article: http://heanoti.com/index.php/hn/article/view/hn50306

\title{
Profile of Age and Sex of Congenital Rubella Syndrome Patients with Congenital Heart Disease
}

\begin{tabular}{c} 
Chaq El Chaq Zamzam Multazam ${ }^{1(\mathrm{CA})}$, Mahrus A. Rahman' ${ }^{2}$, Wiwin Retnowati \\
${ }^{3}$ \\
${ }^{1(\mathrm{CA})}$ Medicine Faculty, Universitas Airlangga, Indonesia; chaq.el.chaq-2017@fk.unair.ac.id \\
${ }^{2}$ Department of Pediatric, Dr Soetomo Regional Public Hospital, Indonesia; mahrus.a@ fk.unair.ac.id \\
${ }^{3}$ Department of Microbiology, Medicine Faculty, Universitas Airlangga, Indonesia; wiwin-r@ fk.unair.ac.id \\
(Corresponding Author) \\
\hline
\end{tabular}

\section{ABSTRACT}

Background: Rubella is an acute viral disease that often attacks vulnerable children and young adults throughout the world. Even though it only causes mild clinical illness, concern in the health world arises from its teratogenic potential resulting in congenital rubella syndrome (CRS). The most common abnormalities of CRS are hearing loss or deafness, eye defects and congenital heart defects. Purpose: To determine the profiles of age and sex in congenital rubella syndrome patients with congenital heart disease in Dr Soetomo Regional Public Hospital for the period of 2016-2018. Methods: This type of research was a descriptive study by collecting data on the age and sex in congenital rubella syndrome patients with congenital heart disease in Dr Soetomo Regional Public Hospital retrospectively through medical records of patients for the period of 2016-2018. Results: The most age group of congenital rubella syndrome patients with congenital heart disease in Dr Soetomo Regional Public Hospital for the period of 2016-2018 was the toddler (0-<5year), whereas sex group was the same in number.

Keywords: congenital rubella syndrome; congenital heart disease; age; sex

\section{INTRODUCTION}

Rubella is an acute viral disease that frequently affects susceptible children and young adults around the world. Although the symptoms maybe mild clinically, but it has a potential teratogenic side effect during pregnancy which causes congenital rubella syndrome (CRS). Rubella infection can cause multiple abnormalities in the fetus, up to $90 \%$ of cases, and may result in miscarriage or stillbirth since before conception to the first 8 10 weeks of pregnancy. After 18 weeks, risk of congenital rubella syndrome is low. The most common abnormalities are hearing loss and deafness, eye defects and congenital heart defects ${ }^{(1)}$.

One of the abnormalities in congenital rubella syndrome is congenital heart disease. Congenital heart disease is an abnormality in the structure or function of the heart circulation that occurs at birth. This malformation usually occurs as a result of changes in the normal structure during the development of embryo. It is closely related to the underlying genetic disorders, either directly related to the environment or the result of the interaction between multifactorial genetics and the environment ${ }^{(2)}$.

Until 2019, the profile of congenital rubella syndrome syndrome with congenital heart disease in Dr. Soetomo Regional Public Hospital, Surabaya, has not been studied much so it is necessary to conduct research to be used as a reference in congenital syndrome syndromes, especially those related to the manifestations of congenital heart disease.

The aim of this study was to evaluate profile of age and sex of congenital rubella syndrome patients with congenital heart disease in Dr. Soetomo Regional Public Hospital, Surabaya.

\section{METHODS}

This was a descriptive study which collecting data on the age and sex of congenital rubella syndrome patients with congenital heart disease in Dr. Soetomo Regional Public Hospital, Surabaya, retrospectively through patient's medical records from 2016 until 2018.

The study samples were all patients with congenital rubella syndrome who suffered from congenital heart disease aged 18 years and under which were treated in outpatient clinics of Eye, ENT (Ear, Nose Throat), and Children's Health Sciences at Dr. Soetomo Regional Public Hospital, Surabaya, for the period of 2016 to 2018.

The study variables were age and sex. Age is the time span measured from birth to the first visit at Dr. Soetomo Regional Public Hospital based on medical records. Ages are grouped based on the classification of the

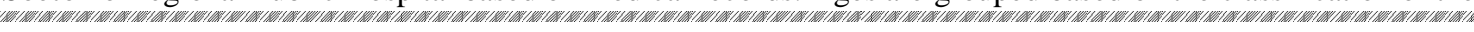
100 | Publisher : Humanistic Network for Science and Technology 
Indonesian Ministry of Health (2009) into under five (0-5 years), children (6-11 years), adolescents (12-18 years), using an ordinal scale. sex, male and female, biologically from birth according to medical records, using a nominal scale.

This study was carried out from the Medical Records from the outpatient clinics of Eye, ENT, and Pediatrics at Dr. Soetomo Regional Public Hospital, Surabaya, from May 2019 to May 2020. Data was collected from medical records in data collection sheets, which were carried out on working days and hours. The data was presented in tabular form and analyzed descriptively.

\section{RESULTS}

Age

Based on the distribution table 1, patients with congenital rubella syndrome with congenital heart disease were mostly found in the under five age group $(0-<5$ years), namely 28 patients $(87.5 \%)$, while the frequency of children were the lowest, namely 4 patients $(12.5 \%)$. There were no adolescents (12-18 years) patients.

Table 1. Age distribution of congenital rubella syndrome patients with congenital heart disease

\begin{tabular}{ccc}
\hline Age & Frequency & Percentage \\
\hline Toddler $(0-5$ years $)$ & 28 & 87.5 \\
Children $(5-11$ years $)$ & 4 & 12.5 \\
Adolescent $(12-18$ years $)$ & 0 & 0.0 \\
\hline
\end{tabular}

Sex

Based on table 2, patients with congenital rubella syndrome with congenital heart disease were admitted to Dr. Soetomo Regional Public Hospital had the same distribution between women and men. Of the total 32 patients, 16 patients $(50 \%)$ were female, while 16 were male $(50 \%)$.

Table 2. Sex distribution of congenital rubella syndrome patients with congenital heart disease

\begin{tabular}{ccc}
\hline Sex & Frequency & Percentage \\
\hline Male & 16 & 50 \\
Female & 16 & 50 \\
\hline
\end{tabular}

Age

\section{DISCUSSION}

Many studies on CRS have been carried out both in Indonesia and internationally. Study at Dr. Sardjito Hospital, Yogyakarta identified cases of CRS in infants aged $<1$ year, obtained 7 out of $11(63.6 \%)$ aged $1-5$ months ${ }^{(3)}$. Whereas a study in South Africa reported the age of diagnosis for CRS ranged from 0 - 11 months with the majority of cases diagnosed at 4 weeks after delivery ${ }^{(4)}$. Studies at the Gondar University Referral Hospital show mostly $(66.7 \%)$ occur in infants aged $1-5$ months $^{(5)}$. Internationally, several countries have conducted national surveillance. Based on the 2016-2018 surveillance about CRS in India, the mean age of laboratory-confirmed infants was 3.7 months $^{(6)}$. While the CRS surveillance in 5 countries in Africa showed that most $(43 \%)$ were aged 6-11 months while 21 of them were newborns ${ }^{(7)}$. The Spanish national surveillance from 1997-2016 showed that most of the diagnoses were made in the first month after birth ${ }^{(8)}$. Of all the results of the study and surveillance, none of them showed age of the first diagnosis more than 5 years old, while our results mentioned 4 patients $(12.5 \%)$ aged 5-11 years. This can occur due to several things, such as different age exclusion inclusion criteria. In addition, the operational definition of age in our study was the age of the first visit at Dr Soetomo Regional Public Hospital which may had been already diagnosed at a previous health service.

The previous theory explained that the signs and symptoms of CRS started at birth or more prominent as the child grows. Some signs were seen at neonate, as well as several other disorders appear after the age of 2 years $^{(4)}$, until the age of 4 years. Whereas late onset CRS can manifest as diabetes, thyroid dysfunction, and visual or neurological abnormalities ${ }^{(9)}$. The results of this study supported the results of our study where CRS patients with CHD were mostly found in the under-five age group ( 0 - <5 years), namely 28 patients $(87.5 \%)$.

Diagnosis made from newborns when the tissue damage had occurred intrauterine ${ }^{(4)}$. As infants approach 1 year of age, laboratory confirmation becomes more difficult because negative rubella test results do not exclude $\mathrm{CRS}^{(4)}$. IgM antibodies were sometimes found up to 1 year of age, and the persistence of $\operatorname{IgG}$ antibodies beyond 6 months of age has been detected ${ }^{(7)}$. However, many cases were diagnosed in specialist clinics when the children were over 1 year old age ${ }^{(4)}$. In our study, children group of age patients with SRK with CHD had a lower frequency than under five group, namely 4 patients $(12.5 \%)$. 
Study on CHD had been widely conducted and showed results similar to ours. Previous studies at RSUD Dr. Soetomo regarding Asianotic CHD showed the largest group of 179 patients $(72.47 \%)$ aged under five (0 $<5$ years), $47(19.03 \%)$ patients with children, and 21 patients $(8.50 \%)$ adolescents $^{(10)}$. A study at Sardjito Hospital, Yogyakarta showed $78 \%$ of cases of children ranging in age 0 days to 17 years $(2.7 \pm 4.4 \text { years })^{(11)}$. Study at Dr. M. Djamil Central Public Hospital, Padang, showed an average age of 1 month until 1 year ${ }^{(12)}$. Studies at the Lagos State Teaching Hospital, Nigeria showed an age range of 2 days to 35 years with a mean of $32.50 \pm 48.06$ months $^{(13)}$.

CHD generally caused clinical symptoms early in life. These signs and symptoms could be found from birth, such as recurrent respiratory infections and difficulty of gaining weight, a minimal one, which could no $^{(14)} t$ be detected until adulthood. The difference in the age of diagnosis of CHD patients depend on the type and complexity of the disorder ${ }^{(10)}$. In developed countries, the diagnosis of CHD was carried out during the prenatal or neonatal period. Delayed diagnosing was often caused by human resources and limited diagnostic services. It caused patients over 5 years of age were still found in our study.

Study on CRS with CHD was also carried out. A systematic review also stated that CHD found mostly in children aged 2 years and under (26-80\%) than a study that reported children over 2 years (4-55\%) of all CRS cases $^{(15)}$. In Dr. Soetomo Regional Public Hospital, a comparative study had not been conducted between the ages of CRS sufferers with or without CHD until now.

Sex

The results of various previous studies on CRS showed a male predominance. The 2016-2018 Indian CRS surveillance was dominated by men as many as 377 children $(58.5 \%)^{(6)}$. The Spanish CRS surveillance from 1997-2016 was dominated by males as many as 14 cases $(63.6 \%)^{(8)}$. A study at the Felege-Hiwot Reference Hospital, Gondar University, shows a male sex dominance of $55.6 \%{ }^{(5)}$. Whereas the study in South Africa was predominantly male, namely 51 out of 86 cases $(59 \%)^{(4)}$..

During infancy and childhood, the severity and prevalence of viral infections were generally higher in males. However, female reported stronger humoral and cellular immune responses to infection or antigenic stimulation. This strong level of immunity could be beneficial in protecting and clearing pathogens but the negative effect was increasing immunopathology of certain infectious diseases ${ }^{(16)}$. The mechanisms underlying sex differences in immune responses were related to hormonal differences, genetic and epigenetic regulation, and microbiome ${ }^{(17)}$. For example, there was an intermittent surge of sex steroid hormones during infancy that affects immune response especially the balance of T-helper 1 / T-helper 2 cytokines. Testosterone, progesterone, and estradiol modulate lymphocyte, dendritic cell and macrophage function. Testosterone has an immunosuppressive effect in reducing the secretion of interferon (IFN) $\gamma$ and interleukin 4 in T cells. Estrogens can increase the Th1 cellular immune response at low doses and increase Th2 response and humoral immunity at high concentrations ${ }^{(16)}$. In addition, female known to have a higher antibody response to the vaccine. After the rubella vaccination, the protective antibody response of female can reach two times higher than male. In several other vaccines, the cellular immunity was higher in women ${ }^{(17)}$.

On the other hand, various studies on CHD are predominantly female. Asianotic CHD study at Dr. Soetomo General Public Hospital showed that 133 patients $(53.85 \%)$ were female ${ }^{(10)}$. Studies at Djamil General Hospital, Padang also show female predominance in 2012 and $2015,51 \%$ and $61.8 \%$, respectively ${ }^{(12 ; 18)}$. A study at Sardjito Hospital, Yogyakarta showed the female predominance as much as $60 \%{ }^{(11)}$. A study at the Lagos State University Teaching Hospital showed a male to female ratio of 1: $1.1^{(13)}$.

Several factors can explain the predominance of female sex in CHD. Female has smaller artery diameter, as well as higher risk for endothelial dysfunction of blood vessels than male. Both of them support the occurrence of pulmonary artery hypertension which can further lead to congenital heart disease. In addition, spontaneous closure of the septal defect is more common in male. Therefore, the previous research at RSUD Dr. Soetomo also showed the dominance of female sex in atrial and ventricular septal defects ${ }^{(10)}$.

Finally, male dominance in CRS, female dominance in CHD, as well as the equal number of CRS with CHD were the base of our results which showed that CRS patients with CHD treated at Dr. Soetomo General Public Hospital had the same sex distribution between male and female.

\section{CONCLUSION}

Based on the results and discussion, two conclusions were drawn. First, the age group of patients with congenital rubella syndrome with congenital heart disease in the Dr. Soetomo Regional Public Hospital from 2016 to 2018 was mostly under five $(0-<5$ years) age group, namely 28 patients $(87.5 \%)$. Second, the sex of patients with congenital rubella syndrome with congenital heart disease in the Dr. Soetomo Regional Public Hospital for the period of 2016-2018 was equal both men and women, respectively (50\%). 


\section{REFERENCES}

1. World Health Organization. Congenital Rubella Syndrome: Vaccine-Preventable Diseases Surveillance Standards. 2018;3-12.

2. Braunwald E, Mann DL, Zipes DP, Libby P, Bonow RO. (Ed). Braunwald's Heart Disease. 10th ed. Philadelphia: Elsevier; 2015;1391-1393.

3. Herini E, Gunadi, Triono A, Mulyadi A, Mardin N, Rusipah, Soenarto Y, Reef S. Hospital-based surveillance of congenital rubella syndrome in Indonesia. European Journal of Pediatrics. 2017;176(3):387-393.

4. Motaze NV, Manamela J, Smit S, Rabie H, Harper K, Duplessis N, et al. Congenital rubella syndrome surveillance in South Africa using a sentinel site approach: a cross-sectional study. Clinical Infectious Diseases. 2019;68(10):1658-1664.

5. Wondimeneh Y, Tiruneh M, Ferede G, Denekew K, Admassu F, Tessema B. Hospital based surveillance of congenital rubella syndrome cases in the pre-vaccine era in Amhara Regional State, Ethiopia: A base line information for the country. PloS One. 2018;13(11).

6. Murhekar M, Verma S, Singh K, Bavdekar A, Benakappa N, Santhanam S, et al. Epidemiology of Congenital Rubella Syndrome (CRS) in India, 2016-18, based on data from sentinel surveillance. PLoS neglected tropical diseases. 2020;14(2).

7. Masresha B, Shibeshi M, Kaiser R, Luce R, Katsande R, Mihigo R. Congenital Rubella Syndrome in The African Region-Data from Sentinel Surveillance. Journal of immunological sciences. 2018;146.

8. Seppälä EM, López-Perea N, de Mier MDVT, Echevarría JE, Fernández-García A, Masa-Calles J. Last cases of rubella and congenital rubella syndrome in Spain, 1997-2016: the success of a vaccination program. Vaccine. 2019;37(1):169-175.

9. European Centre for Disease Prevention and Control. Disease Factsheet About Congenital Rubella Syndrome (CRS). [Internet]. 2020 [cited 2020 Jun 16]. Available from: https://www.ecdc.europa.eu/en/congenital-rubella-syndrome/facts

10. Fedora K. Profil Penyakit Jantung Bawaan Asianotik Pada Anak Di Unit Rawat Jalan Departemen/Smf Ilmu Kesehatan Anak RSUD Dr. Soetomo Surabaya Periode Januari-Desember 2016. Doctoral Dissertation. Surabaya: Universitas Airlangga; 2018.

11. Ismail MT, Hidayati F, Krisdinarti L, Noormanto N, Nugroho S, Wahab AS. Epidemiological profile of congenital heart disease in a national referral hospital. ACI (Acta Cardiologia Indonesiana). 2015;1(2).

12. Hariyanto D. Profil Penyakit Jantung Bawaan di Instalasi Rawat Inap Anak RSUP Dr. M. Djamil Padang Januari 2008-Februari 2011. Sari Pediatri. 2016;14(3):152-7.

13. Animasahun BA, Adekunle MO, Kusimo OY. Time to diagnosis, socioeconomic and clinical features of patients with congenital heart diseases in a teaching hospital in Nigeria. J Public Health Emerg. 2018;2:17.

14. Abah, et al. Pattern of Cardiac Disease Among Children in A Tertiary Hospital in North Central, Nigeria: A Three and Half Years Retrospective Cohort Echocardiographic Study. African Journals Online (AJOL). 2018;8-9.

15. Simons EA, Reef SE, Cooper LZ, Zimmerman L, Thompson KM. Systematic review of the manifestations of congenital rubella syndrome in infants and characterization of disability-adjusted life years (DALYs). Risk Analysis. 2016;36(7):1332-1356.

16. Muenchhoff M, Goulder PJ. Sex differences in pediatric infectious diseases. The Journal of infectious diseases. 2014;120-126.

17. Klein SL, Marriott I, Fish EN. Sex-based differences in immune function and responses to vaccination. Transactions of the Royal Society of Tropical Medicine and Hygiene. 2015;109(1): 9-15.

18. Ain N, Hariyanto D, Rusdan S. Karakteristik penderita penyakit jantung bawaan pada anak di RSUP dr. M. Djamil Padang periode Januari 2010-Mei 2012. Jurnal Kesehatan Andalas. 2015;4(3). 